\title{
Commercial breaks: an overview of corporate opportunities for commercializing education in US and English schools
}

\author{
Gary Wilkinson* \\ University of Hull, UK
}

This article outlines how the commercialization of structures and management in education risks accelerating the intensification of corporate marketing in schools. It is argued that marketing promotes materialistic values which are harmful to children and US and UK examples are offered to demonstrate how companies seek to use schools as brand-building sites. The article argues that these activities pose a threat to children and to the integrity and purposes of education.

\section{Introduction}

In January, 2006, Helen Jones, Member of Parliament for Warrington North, asked Ruth Kelly, New Labour's then Secretary of State for Education, to be 'more specific' about who might oversee the trust schools proposed in her draft education bill and, pointedly, whether 'firms such as McDonald's, for instance, would technically be able to run trusts' (Hansard, 2006). Unable to provide reassurance, the minister could only avoid embarrassment by sidestepping the question. The White Paper, Higher standards, better schools for all: more choice for parents and pupils (DfESa, 2005), published the previous November, mapped a blueprint for a system of independent state schools and Kelly was now struggling to rescue her draft education bill. A key issue concerned the devolution of powers to trust schools operating outside of local authority control. For many on the left the invocation of the planet's biggest fast food chain controlling state schools reminded the House that the implications of corporate involvement in education are profound indeed.

\footnotetext{
* Scarborough School of Education, University of Hull, Filey Road, Scarborough YO11 3AZ, UK. Email: G.P.Wilkinson@hull.ac.uk
} 
The commercialization of education began with the new right's agenda during the 1980s which sought to reform the bureaucratic and monolithic structures of the welfare state. Their policies involved the introduction of 'quasi-markets' (Glennerster, 1991), business management techniques or 'managerialism' (Pollitt, 1990) and the privatization or contracting out of services in order to promote competition, choice and diversity of provision. These policies also created new sites for private profit. Crouch (2003) argues that the mid-twentieth century welfare settlement in the UK was premised on the belief that certain essential services were an entitlement in a democratic society. These 'citizenship services' were distinct from 'market services'. He contends that post-industrial capitalism has unpicked this part of the post-war welfare consensus to the extent that the new public management since the 1980s has brought about 'a redefinition of the boundary between the Government and private interests as a semi-permeable one' (Crouch, 2003, p. 17). New Labour has continued much of this agenda and is now seeking to expand the role of business and other private groups in school governance. Yet many Labour MPs remain uneasy about the involvement of big business in education and the sidelining of local education authorities which provided a link to local democratic accountability.

Alongside these structural and managerial dimensions of commercialization, we have seen a growing trend of companies using schools as marketing sites to sell their products and develop brand loyalty. This represents the commercialization of educational space as the special character of these public areas, hitherto relatively free from commercial activity, is transformed. Schools are becoming key sites where companies seek competitive advantage by marketing to children. Now that corporate interests have a growing presence in the provision and running of educational services, the different dimensions of commercialization may coalesce to present a threat to the civic purposes of education as preparation for democratic participation. This article outlines how a culture of commercialization may lead to an impoverished education system in which capitalistic world views and materialistic consumption are actively promoted in schools as the business world seeks to profit from and within schools by selling brands and products to children. The giving over of educational space in terms of terms of buildings and curriculum is a subversion of the proper purposes of civic education and harmful to children. It is also a distortion of the market principle of consumer freedom and sovereignty, since children are compelled to attend school.

The article begins by highlighting some aspects of the commercialization of structures and management in education. Some research on the nature and effects of corporate marketing, or propaganda, is then presented as a preface to the central discussion on marketing in schools. Parallels with the US are drawn throughout. In conclusion, the absence of any national regulations on corporate brand-building activity in schools is noted and it is argued that policies which commercialize structures and management may operate to accelerate the commercialization of educational space. Meanwhile, the UK Government seems concerned only to welcome the business world into the staffrooms and classrooms of England. 


\section{The commercialization of structure and management}

The neo-liberalism of the Thatcher and Reagan eras clung to the sanctity of the free market as the most effective mechanism for social and economic organization. In order to bring about change in education, they wrought changes which might make the provision of public services more closely resemble a market model. Their commercializing measures were 'premised on the assumption that the quality of public services will be improved if the existing practices and ethos of public service are replaced by those typical of commercial practice' (Crouch, 2003, p. 4). There was a need therefore to change both the organizational model of educational services and the way in which they were managed. This has involved 'the modeling of the internal and external relations of schooling and public service provision more generally upon those of commercial market institutions' (Ball, 1999, p. 197). The commercialization of education, which began with their radical public service reform agendas, has therefore focused primarily on structure and management.

As Leader of the Opposition, Tony Blair dismissed the Conservatives market solutions in a speech at Ruskin College in 1996:

In the 1980s, the Right claimed to have an easy answer to the questions posed by Jim Callaghan. The market would deliver education reform. 'Focus on structures and standards will come good'. But the truth is that we know the qualities that make a successful school ... and changing the structures doesn't alter the need to imbue every school with these qualities. Culture, attitude and expectations are critical to successful education, and they exist whether or not we have a market in education. (Blair, 1996)

New Labour adopted this mantra of 'standards not structures' and, once in power, introduced a raft of powerful interventionist policies designed to address standards in the basics of English and mathematics and compensatory measures to help those in disadvantaged areas in their first education white paper, Excellence in schools (DFEE, 1997). Since then, however, there has been a steady shift to a focus on structures throughout New Labour's tenure. As The White Paper, Higher standards, better schools for all: more choice for parents and pupils (DfESa, 2005) demonstrates, a discourse of freedom, empowerment, choice and diversity now dominates the language of education policy arguing that parents should be able to choose from a range of schools newly liberated to create their own distinctive educational products in a competitive educational market.

Structural commercialization under New Labour, mirroring US policy, has involved the tendering out of educational services and the privatization of school governance though ownership is less important here than control. One example of tendering out in the US is that of educational management organisations (EMOs) running schools or groups of schools for profit. EMOs are big business and the mayor players have organized into the National Council of Education Providers which uses a professional lobbying company as they try to maximize the opportunities for profiting from public money made available for education. The industry is maturing and consolidating power in the hands of fewer larger companies (Molnar, 2004). The Commercialization in Education Research Unit (CERU) at Arizona 
University lists 59 companies managing 535 schools catering for 239,766 students (Molnar et al., 2005). The UK too has witnessed a growth of EMO activity. Education Associates, Nord Anglia, Atkins Education, and Amey have all been enlisted by the Government to turn around failing local authorities. One analysis of the Office for Standards in Education (Ofsted) reports found that those 'forced to surrender services to the private sector have improved less than those who failed an inspection but were allowed to retain control' (Slater, 2003). Cambridge Education Associates did not meet its targets and five of the other nine privatized LEAs were found to be poor. Southwark council lost $£ 1.5$ million in 2003 after its contractor, Atkins Education, withdrew prematurely from its contract. The council leader asserted that the 'termination of a contract with Atkins is in the long-term best interests of Southwark schools, parents and pupils' (Smithers, 2003, p. 10). Some EMOs have global reach. Edison, the subject of much attention in the US, has now turned its attention to the UK. Its web site (Edison Schools UK, 2006) directs us to its work with local authorities in Bradford and Southwark.

The privatization of school governance, which involves the removal of schools from local democratic control, is also seen on both sides of the Atlantic. In the US, there are now over 3500 charter schools which are funded by the public but run by groups of parents, teachers, community leaders and business. Charter schools enjoy delegated school governance with freedom from the usual constraints on public schools and exercise relative autonomy over management of the curriculum, employment arrangements and accommodation. Yet charter schools have so far failed to demonstrate their added educational value. Even the National Alliance for Public Charter Schools (NAPCS, 2006) acknowledges that there is inadequate data to prove their benefits over and above public schools and the US Charter Schools' (2006) web site attests only to improvements in parental satisfaction.

During New Labour's early years in office, a favourite form of co-opting the private sector into educational management was corporate 'sponsorship' connected to major programmatic strategies. It involved companies donating money, or goods in kind, to a project in exchange for some say in its running. Education Acton Zones, for example, co-opted Shell, British Aerospace, Tesco, ICI, Cadbury Schweppes, McDonald's and Kellogg amongst others to have a say in the umbrella governance of groups of English schools (Cohen, 2000). The idea has been extended to individual schools too. City Technology Colleges, Specialist Schools and City Academies all have connections with an external partner or 'sponsor'. Their role is particularly controversial in the case of City Academies, where sponsors control in whole or part the staffing, admissions, accommodation, curriculum and governance arrangements. The National Union of Teachers (NUTa, 2006, p. 1) opposes them on the grounds that they involve 'the transfer of publicly funded assets to the control of an unaccountable sponsoring body'. They also point out that the benefits for sponsors include 'school buildings and grounds, Academy supply contracts, advertising, developing the kind of workers they need'. The arrest of Des Smith in a 'cash-forpeerages' investigation in April, 2006, suggests that individuals may benefit too. A council member of the Specialist Schools and Academies Trust, he admitted to a 
Sunday Times reporter that the Government rewarded sponsors with knighthoods and peerages (Smithers \& Pallister, 2006). As of July 2006, there are 27 open for business and Amey plc, Reed Executive plc, SGI Ltd, Seabourne Group plc, Insinger Townsley, Pfizer and Dixons are among the corporate backers. A further 82 are at the 'development stage' and sponsors include property developers Chelsfield plc, interactive media consultants IM Group Limited, HSBC, Granada Learning, who produce educational resources, and UBS, a financial services company (DfESb, 2006).

Choice is new watchword of Government policy as the Prime Minister underlined in his 2005 Labour Party conference speech:

There's a great myth here: which is that we don't have a market in services now. We do. It's called private schools and private healthcare. But it's only open to the well-off. ... Choice is what wealthy people have exercised for centuries. The Tories have always been comfortable with that. But for Labour choice is too important to be the monopoly of the wealthy. (Blair, 2005a)

It is clear, then, that these forms of privatized schools are part of a political agenda to create public sector diversity and choice by developing a range of school 'products' operating within educational markets. Wrapped up with this is the unsubstantiated presumption that external partners from the dynamic world of the private sector are best positioned to deliver this. In Tony Blair's words, 'it is no coincidence that results at every level have been better in specialist schools and academies where they have had more freedom to innovate and a greater involvement of external partners' (Blair, 2005b). The newly proposed trust schools, mirroring US charter schools in many respects, 'will harness the external support and a success culture, bringing innovative and stronger leadership to the school, improving standards and extending choice' (DfESa, 2005a, p. 24). Yet, despite the Prime Minister's remarks, there is no hard evidence to suggest that corporate involvement in school governance produces a more effective education service. The Select Committee of the House of Commons report that 'No causal link has been demonstrated between external partners and the success of a school, or between the independence of a school from local authority control and its success' (Education and Skills Committee, 2006, para. 50).

Professionals, who serve the transcendental values of the professional ideal, can be distinguished from those serving the consumer in the market or the rulebook of the bureaucracy (Freidson, 2001). Yet, whilst successive Governments have sought to harness the talents of the business world to education management, policies associated with 'managerialism' (Pollitt, 1990) have changed the way in which public sector professionals work. These 'global policyscapes' are broad policy paradigms which converge around centralization and prescription, choice and competition and autonomy and performativity (Ball, 1999, p. 196). The focus on outcomes and efficiency, as determined by national performance indicators such as tests and inspection data, has produced a culture in which what teachers perceive to be the educational priorities of children take second place to the priorities of the school or state (Ball, 2003, 2004). The effect has been to transform the behaviour, language 
and thinking of educational professionals and to change their professional identities (Dent \& Whitehead, 2002).

The subtleties of the professional-colleague model have shifted to a more commercialized model and staff in schools are forced into competition for resources. The same commercial mindset has had a dramatic impact on US higher education. Slaughter and Rhoades' (2004) 'academic capitalism' characterizes the contemporary acceptance of knowledge privatization and profit in universities, whilst Bok (2003, p. 54) claims that the new commercial mindset in many universities has 'compromised the fundamental purpose of academic institutions'. In schools too the entrepreneurial spirit has led some educational leaders to develop an unusual sense of educational priorities which undermine the purposes and principles of civic education. Molnar (2005, pp. 40-41) records how in Colorado Springs District the executive director of school leadership contracted into an agreement with Coca-Cola who became exclusive suppliers of soft drinks for the district's schools. Finding that children had not consumed enough to trigger the maximum financial benefit from the agreement, he issued a memorandum which urged school principals to encourage children to buy more Coke at school. In Florida, children traveling to school found that their school district had attempted to circumvent state rules prohibiting advertising on the outside of school buses by selling advertising space on the inside of the windows.

The response of educational mangers to commercialization in the US is reflected in UK schools. If financial incentives have been offered to schools opting to participate in Government initiatives involving business, we should not be surprised when school leaders take the opportunity to seek advantage for their schools. Incentives in the form of autonomy to depart from the national curriculum, vary levels of pay and experiment with staffing models are now open to schools controlled by external partners in flagship initiatives, such as city academies sponsored and run by business, religious and charitable organisations. The reaction of teacher unions suggests that this is not an agenda that has the wholehearted support of the teaching workforce. In response to the recent White Paper, John Dunford, General Secretary of the Secondary Heads Association (SHA), argued that:

School leaders welcome greater freedom for schools, but the freedoms being offered in the White Paper are largely an illusion. ... The White Paper should have contained more on schools working together so that the state school system does not break up into 3500 small, independent units. (Dunford, 2005)

He goes on to call for increased partnership among schools rather than with business or other sponsors and criticizes the 'mirage' of parental choice. Teachers, educational managers and schools have not always been forced to comply with all the commercializing measures of the reform programme and some individual schools may have welcomed the greater freedoms and opportunity to work with sponsors and business. But all are compelled to operate within a commercialized system and those who reject the opportunity to co-opt businessmen and women into school governance may find themselves receiving less public funding than those who 
embrace the new zeitgeist. The responses of the NUT and SHA certainly lend weight to the interpretation that political and ideological faith in markets and business drive the commercialization agenda, rather than educational imperatives.

\section{The rise of corporate propaganda for children}

In his sweeping history of American marketing, PR! A social history of spin, Stuart Ewen (1996) chronicles the history of the US public relations (PR) industry throughout the twentieth century. As it evolved, drawing on the finding of developmental and social psychology, it became ever more professional in its attempts to create a 'precarious architecture of truth' (Ewen, 1996, p. 148). Edward Bernays, the founding father of modern public relations, published Propaganda in 1928 which laid down the underlying principles of modern marketing and the work of 'PR counsel'. The objective of PR professionals, he advised, was to create a positive climate for their clients by manufacturing newsworthy events and simulating enthusiasm in an attempt to elicit an emotionally favourable response to the company and its product. He advocated a society 'organized by leadership and propaganda' (Bernays, 2005, p. 39). The increasingly sophisticated propaganda techniques used by the corporate world since Bernays go beyond attempts to inform and persuade consumers of the merits of their brand. The ultimate aim is to 'erect an emotionally captivating corporate cosmology' (Ewen, op cit., p. 385) which secures emotional attachment to the company and its products and activities.

There is growing evidence and concern that exposure to modern marketing and the materialistic ideology it promotes is antagonistic to both the common good and individual well-being. Kasser's (2002) review of the research examining how materialistic attitudes to money, possessions and consumption affect well-being is illuminating. Higher materialistic values are related to lower self-esteem, chronic physical symptoms and higher rates of anxiety, depression and psychological distress. In teenage children, higher materialistic values also correlate with increased smoking, drinking, drug use, carrying weapons, vandalism and truancy. The ideology of consumerism is especially harmful to school-aged children. Schor's research with this group links media use, advertising and involvement in the consumer marketplace to test well-being. She reports:

High consumer involvement is a significant cause of depression, anxiety, low selfesteem, and psychosomatic complaints. Psychologically healthy children will be made worse off if they become more enmeshed in the culture of getting and spending. Children with emotional problems will be helped if they disengage from the worlds that corporations are constructing for them. (Schor, 2004, p. 167)

She also found consumer involvement detracts from other beneficial activities and creates tensions in families which have a negative effect on well-being and behaviour. Watching television was found to be a particularly effective way of increasing children's involvement in consumer culture and Schor argues that corporate marketing carries a message which inverts patterns of school and parental authority and gives prestige to that which adults oppose. 
There are compelling objections to the content of products and the associated marketing propaganda. Inappropriately sexualized images in toys, apparel and accessories aimed at girls are commonplace. Dolls with idealized bodies now wear make-up and sexually provocative clothing. Giroux (2001) has described how the sexualization of children can also be seen in the commercialized world of child beauty pageants in the US where companies provide sponsorship and sell merchandise. In England, Louise Evans, a spokeswoman for W. H. Smith, defended the stationer's belief in consumer freedom as the company was criticized for selling pencil cases to school children bearing the Playboy logo. 'We offer customers choice', she proclaimed, adding that 'We're not here to act as a moral censor' (quoted in Bell, 2005, p. 6). Products and propaganda aimed at boys often glamorize violence and cover a range of formats including video games, films, popular music and action figures. Billions of PR dollars are invested in the marketing of junk food to both sexes. Companies selling sweets, soft drinks and fast food target products at the young, such as McDonald's 'Happy Meals', and employ sportspeople to lend an air of healthy respectability to non-nutritious 'foods' as in the case of the ex-England footballer and sports presenter Gary Lineker and his adverting contract with Walker's crisps. The rise of child obesity in both the US and the UK has meant that such marketing campaigns have now brought this issue into public consciousness.

Such marketing is increasingly targeted at children of younger ages. Linn's (2005) research into the advertising industry describes the phenomena of age compression where advertising and products aimed at older children reaches those of younger ages as marketers try to attract 'tweens', those of 6- to 11-years who are considered to be in-between children and teenagers. PR departments also use children in market research. Their techniques, which are unregulated, are often intrusive and exploitative. 'Relationship mining' (Linn, 2005, p. 36), for example, strives to understand the dynamics of family conflict in order to exploit it for marketing purposes. Even where children are paid for their creative ideas they have no intellectual property rights. When carried out in schools, children may be forced to participate or be unaware that they are engaged in market research.

With the prime objective of selling brands and making money, corporations and the PR industry can be unscrupulous in the way in which they market to children. Some appear to be engaged in cynical and calculated psychological exploitation:

... advertising at its best is making people feel that without their product, you're a loser. Kids are very sensitive to that. ... You open up emotional vulnerabilities and it's very easy to do with kids because they're the most emotionally vulnerable. (Advertising executive quoted in Schor, 2004, p. 65)

Given the scientific techniques of modern PR, the ethics of marketing to children at all must be questionable. But, although marketing propaganda is ubiquitous in both public spaces and the media, schools have traditionally been relatively free from such materials. Recent years have, however, seen an intensification of this corporate intrusion which commercializes the curriculum and educational space in an attempt to build brand loyalty and sell to children. Indeed, some companies' raison d'etre is 
the creation of curricular propaganda in a range of media. The sales pitch of Lifetime Learning Systems makes quite clear the primary purpose of its educational materials:

Having created over 2000 programs, Lifetime Learning Systems knows how to link a sponsor's message to curriculum standards and create a powerful presence for your message in America's classrooms with informative and engaging materials. (Lifetime Learning Systems, 2006)

Enterprise for Education produces branded educational materials bearing clients' logos and advertising puff. It reassures clients that its propaganda successfully masquerades as genuine pedagogical tools: 'Your message will be carried into the classroom and understood for one simple reason: Teachers and students take Enterprise's materials seriously and use them effectively!' (Enterprise for Education, 2006).

Propaganda in schools can be seen as a third manifestation of commercialization in education which is operating in tandem with the structural and managerial commercialisms discussed earlier.

\section{Commercializing educational space}

In the US, corporate marketing activities take many forms and intrude upon the entire US school system. The US Consumers Union's (1998) survey of commercialization in schools, Captive kids: a report on commercial pressures on kids at school, identified four main forms which this corporate propaganda takes: corporate-sponsored contests and incentives; overt advertising in and around school; corporate-sponsored educational materials; and direct advertising within classroom materials and broadcast media. These techniques are now finding their way into UK schools.

Klein (2001) recounts an incident at Greenbriar High School in Georgia which illustrates the pernicious effects of one marketing tool, the sponsored competition. As part of its entry to the Coca-Cola's $\$ 500$ prize-winning competition which involved designing a distribution strategy for the company, the school declared a 'Coke Day'. Choreographed pupils posed for pictures and company executives provided engaging talks about the pleasures of Coca-Cola. One student was sufficiently off message to warrant suspension. He had come to school wearing a t-shirt with a Pepsi logo. In the UK, multinationals have already been active in creating corporate-backed competitions. In the run up to the millennium, McDonald's 'Our town story' competition branded children's perspective on local history in return for a day out at the millennium dome (Cohen, 2003).

Although competitions provide intensive publicity at prize-giving time and at the launch, incentive and fundraising schemes provide marketing opportunities over a sustained period as they lock children and parents into buying a company's wares. They also allow the company to profit from increased sales. Campbell's Labels for Education and General Mills' Box Tops for Education are well established in America, but there is no shortage of examples here. Walkers Snack Foods Ltd recently ran a Free Books for Schools campaign in partnership with The Sun and 
News of the World, populist newspapers owned by Rupert Murdoch. Schools could augment their libraries by exchanging tokens collected from the crisp packets and newspapers for books. The Free Books for Schools web site (2006) boasts of providing one school with 1921 books, worth $£ 10,000$. Parents had amassed 385,421 tokens. The school's inspection report (Ofsted, 2004) suggests that the school does not lie in one of the town's more affluent areas. $28 \%$ of children qualify for free school meals and nearly the same proportion has a special educational need, which is well above the national average. Here we see a sinister marriage of a right wing tabloid newspaper magnate and a junk food company infiltrating the homes and educational environment of the poorest children in the country to push their products. The National Audit Office's (2001) report on obesity found that such schemes 'act directly in opposition to initiatives to discourage over-dependence on such energy-dense snack foods' (ibid., para. 4.63) and suggested that schools may not be complying with the National Consumer Council's (1996) good practice guidelines when engaging in this form of business-linked activity. Nestle also runs a voucher scheme, Box Tops for Books, similar to Walker's school books programme

The seeming benevolence of incentive schemes can be deceptive. Cadbury's Get Active campaign in 2003 encouraged children to buy chocolate bars in exchange for school sports equipment. The Food Commission (2003) calculated that:

... to earn the most expensive item Cadbury's has to offer (a set of posts for a volleyball net) secondary school children would need to eat 5,440 chocolate bars containing over $33 \mathrm{~kg}$ of fat and nearly one-and-a-quarter million calories. That's over 900 chocolate bars for each member of the volleyball team.

The Tesco supermarket chain's Computers for Schools voucher scheme is, according to Business in the Community (2003), 'the benchmark for cause-related marketing' and has delivered over $£ 84$ million worth of kit into schools. A Which? (2001) magazine investigation put this into perspective when it calculated that it would require $£ 44,900$ worth of parental shopping to secure a scanner worth $£ 80$ and $£ 220,000$ to earn a school a computer worth $£ 900$.

Some forms of corporate promotional activity proliferate in school and may not be immediately recognizable as marketing. The oldest form of school propaganda and probably the most widespread is the educational resource pack of sponsored 'educational' materials (SEMs). Molnar (2001) directs us to The National Education Association who convened a Committee on Propaganda in the Schools in 1929 to review educational materials from corporations, governments, and other organizations. It reported that:

... the principle of democratic control of curriculum content (generally through an elected school board) is jeopardized by the abundance of unsolicited and unevaluated materials flowing into the schools from well-funded outside interests. (Quoted in Molnar, 2001)

Propaganda continues to flood American and British classrooms.

The Consumers Union (1998) investigated 200 examples of commercially sponsored educational materials ranging from poster kits, videotapes, software, CD-ROMs 
to an array of printed materials. More than half were judged to be commercial or highly commercial in character. They found that:

... nearly 80 percent contained biased or incomplete information, promoting a viewpoint that favors consumption of the sponsor's product or service or a position that favors the company or its economic agenda. A few contained significant inaccuracies. (Consumers Union, 1998, p. 16)

Steel Can Recycling Institute's pack 'Steel—America's most recycled material' promoted the benefits of steel and peddled a distorted perspective on the complexities of sustainable materials. Kellogg's In Kids Get Going With Breakfast provided lopsided health 'education' materials which displayed the company logo. Their lesson on understanding food labeling is a good example of the subtleties of corporate propaganda in the curriculum. It focused on the perils of foods high in fat but completely ignored sugar and sodium content, the focal point of criticism of the companies' breakfast cereal products. Procter \& Gamble's Decision: Earth adopted a novel stance on the ecological friendliness of logging and disposable nappies which provoked environmentalists in 11 states to ask attorneys general to investigate the veracity of these claims.

In the UK, Cadbury's chocolate company has published teaching packs which instruct children that:

... Chocolate is a wholesome food that tastes really good. It is fun to eat at any time of the day and gives you energy and important nutrients that your body needs to work properly. (Cadbury, quoted in Monbiot, 2001, p. 333)

Nestle and has a variety of pseudo-educational resources pushing its products. Its Whole Grain web site (Cereal Partners UK, 2006) promotes its sugar-dense cereals as healthy nutritional alternatives to brown rice and whole-wheat pasta. Cadbury's Learning Zone, an approved site on the Internet-based National Grid For Learning, includes downloadable worksheets for use in classrooms in which every page is branded with the Cadbury's logo.

Kellogg's, in addition to producing educational material on health care and nutrition, sponsors Football in the Community, which provides coaching in schools. The company implores children to 'Earn your stripes' (Kellogg, 2003) by acquiring spurious training aids such as whistles and miniature cones which, predictably, are found in boxes of Frosties or Frosties Chocolate. Branded clothing can be purchased to signify children's commitment to Kellogg's sporting programmes. Kellogg also sponsors the Kellogg's Frosties Amateur Swimming Association Awards Scheme (Amateur Swimming Association, 2006). The two million certificates and badges it annually awards to schoolchildren are branded with Kellogg's child-friendly cartoon mascot. Attaching the company to sports programmes provides an air of respectability and public spiritedness. McDonald's sponsoring the conference of the National Association of Head Teachers offers another example of this technique. Responding to criticism about the appropriateness of allowing the multinational to associate itself with the authority of the association, its general secretary, Mick Brookes, could only reassure the media that he was 'convinced that [McDonald's] are trying to offer healthier choices' (Taylor, 2005b, p. 4). 
Kellogg's sponsorship of sporting activities also acts as direct advertising. Advertising is common in US schools as educational administrators seek to add to their frugal budgets. Molnar (2005) catalogues a wide range of examples which, in addition to the straightforward posting of advertising boards in and around school, includes branded book covers, advertising on school buses, selling naming rights to school buildings and product sampling. A McDonald's-sponsored school in Utah flew the company's flag on school premises, whilst children at an elementary school in Detroit could eat in the mini-McDonald's in the school canteen where the walls were decorated with a mural of McDonald's characters. In Dallas, Dr Pepper's company logo was painted on a school roof so that it could be seen from aircraft leaving or entering the nearby airport. Notwithstanding this, the financial benefit accruing to individual schools from commercial activities is usually a tiny proportion of their overall budget and marketing experts say that their naive amateurism in dealing with the world of commerce means they sell advertising space at rates which are 'grossly under-priced' (Curran, 1999, p. 534).

The most notorious example of advertising in classrooms through broadcast media in the US is Channel One, a controversial project which provides free communications technologies to schools in return for a contractual undertaking committing schools to ensure pupils watch the station during classes. At its peak it reached 12,000 US schools with an audience of more than eight million students. Research has found that its advertisements glamorize an attitude of antiintellectualism (Miller, 1997) and its coverage of political news is narrow in perspective, avoiding issues of economic inequality, class, race or ethnicity (Hoynes, 1997). Children in Channel One schools were more likely to express consumerist and materialistic values (Greenberg \& Brand, 1997) and the poor were more than twice as likely to be subjected to Channel One as their counterparts in more affluent areas (Morgan, 1993).

\section{Conclusion}

Discussing the branding of educational space in US schools, Klein observes that:

... the move to allow advertisements did not take the form of one sweeping decision, but, rather, of thousands of little ones. Usually these were made in an ad hoc, schoolby-school basis, frequently with no debate, no notice, no public scrutiny at all, because advertising agencies were careful to fashion school promotions that could slip between the cracks of standard school-board regulations. (Klein, 2001, p. 102)

In the UK, however, there exist no such regulations and marketing has crept into schools unchallenged. The Department for Education and Skills (DfES) advises enquirers that:

The Department does not publish guidance on advertising at, or through, schools. Decisions on whether to allow advertising on school premises and whether to invite children to carry home advertising material received in school rest with the governing 
body and head teacher of individual schools. The Department is conscious of the amount of material sent to schools but we have no powers to prevent businesses from doing so. (DfES, personal communication, 1 November 2005)

Elsewhere, however, DfES explicitly promotes the many benefits to business if they get involved with schools. Their Education Business Links web site encourages businesses seeking corporate advantage from their involvement with school children, telling them that they 'can acquire better market knowledge, tap into local creativity to develop new products, and gain new and more loyal customers' (DfES, 2006) and promising the 'opportunity to influence the curriculum ... [and] ensure that new recruits come through with the right skills and attitudes' (ibid.). In similar vein, the Technology Colleges Trust (2002, p. 5) asks schools 'to be sensitive to the sponsor's needs, such as to derive some public relations advantage from the deal'. According to the Specialist Schools and Academies Trust, sponsorship gives companies 'Valuable PR exposure' and provides 'innumerable and ongoing opportunities to raise the profile of a particular sponsor' (Specialist Schools and Academies Trust, 2005).

The British Code of Advertising, Sales Promotion and Direct Marketing (Committee of Advertising Practice, 2005) offers guidelines about advertising aimed at children generally but no advice about marketing activity in schools. The only state-endorsed guidance about corporate brand-building is Commercial activities in schools: best practice principles (DfES et al., 2006), which replaces advice previously published by the National Consumer Council (1996). The Incorporated Society for British Advertisers, which describes itself as the voice of British advertisers, were coauthors of the document with the Consumers' Association and DfES. Also involved were the Meat and Livestock Commission, L'Oreal and Proctor and Gamble who, as NUT (2006b) note, are engaged in controversial debates on environmental sustainability, animal and human rights and food safety. It is not surprising, then, to read the assertion on its frontispiece that 'Well thought out commercial activities are of benefit to schools and business'. It recommends that 'the level of branding should be appropriate to the activity' (DfES et al., 2006, p. 3) and that the key principle in deciding whether to use the sponsored resources should be whether 'the educational benefits of the commercial activity outweigh the potential disbenefits' (ibid., p. 2). Such judgments are, for all practical purposes, impossible to make because there is inadequate knowledge about the effects of brand-building exercises on education. What is clear, as we have seen, is that exposing children to the consumerist values which corporate PR promotes can be detrimental to their well-being. For those who believe in the civic mission of education, the 'disbenefits' will always override any educational benefits which can always be otherwise derived within a non-branded pedagogy. The principle of whether advertising or other forms of brand-building are appropriate in schools at all is not a matter which ought to be left to the voice of British advertisers.

The National Union of Teachers opposes the privatization of education represented by the academies model and is 'deeply alarmed at the targeting of schools by businesses seeking simply to market their products and exploit schools, pupils and parents' (NUT, 2006b). It produces some rather more critical guidance on using 
commercial materials in schools (NUT, 2006c). But it is clear that the state remains unconcerned about the commercialization of educational space and untroubled about the ethics of allowing business to seek corporate advantage through its association with children and education.

New Labour's acceptance and fondness for business and its methods is encapsulated in the Prime Minister's remarks to a meeting of venture capitalists. He confided to them that he bore 'the scars on [his] back' from his attempts to his 'get a bit more [entrepreneurship] into the public sector' (quoted in Rawnsley, 2001, p. 298). Attempts to inject the entrepreneurial spirit of the world of commerce into both the management and structure of the education service have now extended to inviting business to run schools. Policies which privatize school governance blur the distinction between citizenship and market services. Without adequate safeguards, they also provide a platform for the corporate world to intensify the commercialization of the curriculum and educational space. There is nothing to prevent a business which controls an academy or trust school selling rights of access to its classrooms for the purposes of market research or joining with its corporate cousins to promote products and brands within school.

State education may fulfil an economic function by preparing children to participate in the labour market and contribute to the national economy. But, as a citizenship service, it must also have the wider objectives of nurturing personal development, social values and political and cultural literacy. For democratic society to function, the primary objective of education must be to empower citizens and strengthen civic unity in a 'struggle for democracy' (Carr \& Hartnett, 1996). In short, as Freire (1982) argued in Pedagogy of the oppressed, education must provide citizens with the tools to read society. Educators, he argued, must be critical cultural workers helping students to understand the socio-political functions of the dominant cultural values and norms and bringing them to challenge oppression and to consider how they might improve democracy. Marketing to children in commercialized schools works directly against such a vision, promoting, as it does, capitalistic perspectives and an ideology of materialistic consumption.

The Member of Parliament who asked about McDonald's controlling a trust might also have worried about any other company selling junk food, junk lifestyles or junk ideas. But, given that all corporations use PR to further their interests and, in the process, attempt to engineer a public mood favourable towards capitalist activities, responsibility for public education should not be delegated to private sector corporations. New Labour's laissez-faire approach towards business in education risks harming children and damaging the purposes and integrity of public education. It is time for those who wish to prevent education becoming a series of commercial breaks for corporate opportunists to bring this debate to the forefront of the public conversation.

\section{Notes on contributor}

Gary Wilkinson is Lecturer in Education at Scarborough School of Education, University of Hull, and writes on education policy issues. 


\section{References}

Amateur Swimming Association (2006) About ASA Awards webpage. Available online at: www.awards.sportcentric.com/vsite/vnavsite/page/directory/0,10853,5061-156504-173720nav-list,00.html (accessed 22 February 2006).

Ball, S. J. (1999) Labour, learning and the economy: a 'policy sociology' perspective, Cambridge Fournal of Education, 29(2), 195-206.

Ball, S. J. (2003) The teacher's soul and the terrors of performativity, fournal of Education Policy, $18(2), 215-228$.

Ball, S. J. (2004) Performativities and fabrications in the education economy: towards the performative society, in: S. J. Ball (Ed.) The Routledge Falmer Reader in sociology of education (London, Routledge), 143-155.

Bell, R. (2005, August 15) It's porn, innit?, The Guardian, p. 6.

Bernays, E. (2005) Propaganda (Brooklyn, NY, Ig Publishing).

Blair, T. (1996) Speech given at Ruskin College, Oxford, 16 December.

Blair, T. (2005a) Speech given at Labour Party conference, 27 September.

Blair, T. (2005b) Minutes of Prime Minister's monthly Downing Street press conference, 11 October.

Bok, D. (2003) Universities in the marketplace: the commercialization of higher education (Princeton, NJ, Princeton University Press).

Business in the Community (2003) Tesco plc - the UK's biggest corporate giver. Available online at: www.bitc.org.uk/news/news_directory/crmtesconews.html (accessed 22 February 2006).

Carr, W. \& Hartnett, A. (1996) Education and the struggle for democracy: the politics of educational ideas (Buckingham, Open University Press).

Cereal Partners UK (2006) Whole grains: the whole story. Available online at: www.wholegrain.co.uk/index.aspx (accessed 15 February 2006).

Cohen, N. (2000) Cruel Britannia: reports on the sinister and the preposterous (London, Verso).

Cohen, N. (2003) Pretty straight guys (London, Faber \& Faber).

Committee of Advertising Practice (2005) The British code of advertising, sales promotion and direct marketing (London, The Committee of Advertising Practice).

Consumers Union (1998) Captive kids: a report on commercial pressures on kids at school. Available online at: www.consumersunion.org/other/captivekids/ (accessed 25 October 2005).

Crouch, C. (2003) Commercialization or citizenship: education policy and the future of public services (London, Fabian Society).

Curran, C. M. (1999) Misplaced marketing - a best buy in advertising: schools selling students as media audiences, The fournal of Consumer Marketing, 16(6), p. 534

Dent, M. \& Whitehead, S. (2002) Managing professional identities: knowledge, performativity and the "new" professional (London, Routledge).

DFEE (1997) Excellence in schools (Sudbury, DfEE Publications).

DfES (2005a) Higher standards, better schools for all: more choice for parents and pupils (Norwich, The Stationery Office).

DfES (2005b) What are academies? Available online at: www.standards.dfes.gov.uk/academies/ (accessed 21 October 2005).

DfES (2006) 'Welcome to the business area' on education business links. Available online at: www.dfes.gov.uk/ebnet/business/ (accessed 14 February 2006)

DfES, Consumers' Association and the Incorporated Society for British Advertisers (2006) Commercial activities in schools: best practice principles. Available online at: www.teachernet.gov.uk (accessed 15 February 2006).

Dunford, J. (2005) White Paper puts rhetoric before reality. Press release, The Secondary Heads Association. Available online at: www.sha.org.uk/cm/news (accessed 27 October 2005).

Edison Schools UK (2006) News and case studies. Online at: www.edisonschools.co.uk/ index.html (accessed 14 February 2006). 
Education and Skills Committee (2006) The schools White Paper: higher standards, better schools for all. First report of session 2005-06 (London, House of Commons).

Enterprise for Education (2006) Why enterprise? Available online at: www.enterpriseforeducation.com/aboutus.html (accessed 14 February 2006).

Ewen, S. (1996) PR! A social history of spin (New York, NY, Basic Books).

Free Books for Schools (2006) Home. Available online at: www.freebooksforschools.co.uk (accessed 14 February 2006).

Freidson, E. (2001) Professionalism: the third logic (Cambridge, Polity Press).

Freire, P. (1982) Pedagogy of the oppressed (Harmondsworth, Penguin).

Food Commission, The (2003) Cadbury wants children to eat two million kg of fat-to get fit, Press Release, 29 April. Available online at: www.foodcomm.org.uk/cadbury_03.htm (accessed 15 February 2006).

Giroux, H. A. (20001) Stealing innocence: corporate culture's war on children (New York, St Martin's Press).

Glennerster, H. (1991) Quasi-markets for education?, The Economic fournal, 101, September, 1268-1276.

Greenberg, B. S. \& Brand, J. E. (1997) Channel One: but what about the advertising?, Educational Leadership, 51, 5-58.

Hansard (2006) House of Commons daily debates, 12 January, 441(91), Column 413.

Hoynes, W. (1997) News for a captive audience. An analysis of Channel One, Fairness and Accuracy in Reporting Extra!, May/June. Available online at: www.fair.org/ index.php?page $=1383$ (accessed 24 October 2005).

Kasser, T. (2002) The high price of materialism (Cambridge, MA, MIT Press).

Kellogg (2003) Earn your stripes. Available online at: www.kelloggs.co.uk/frosties/ (accessed 22 February 2006).

Klein, N. (2001) No logo (London, Flamingo).

Lifetime Learning Systems (2006) Lifetime Learning Systems Inc. Homepage available online at: www.llsweb.com/about.html (accessed 24 October 2005).

Linn, S. (2005) Consuming kids: protecting our children from the onslaught of marketing and advertising (New York, NY, Anchor).

Miller, M. C. (1997) How to be stupid-the lessons of Channel One, Fairness and Accuracy in Reporting Extra!, May/June. Available online at: www.fair.org/index.php?page=1384 (accessed 24 October 2005).

Molnar, A. (2001) Corporate involvement in schools: time for a more critical look (Arizona, Arizona State University, Commercialism in Education Research Unit). Available online at: www.asu.edu/educ/epsl/CERU/Documents/cace-01-01.html (accessed 14 February 2006).

Molnar, A. (2004) Virtually everywhere: marketing to children in America's Schools - the seventh annual report on schoolhouse commercialism trends, 2003-2004 (Arizona, Arizona State University, Commercialism in Education Research Unit) EPSL-0409-103-CERU.

Molnar, A. (2005) School commercialism: from democratic ideal to market commodity (Abingdon, Routledge).

Molnar, A., Garcia, D., Sullivan, C., McEvoy, B. \& Joanou, J. (2005) Profiles of for-profit education management organizations 2004-2005: seventh annual report (Arizona, Arizona State University: Commercialism in Education Research Unit). EPSL-0504-101-CERU.

Monbiot, G. (2001) Captive state: the corporate takeover of Britain (London, Pan).

Morgan, M. (1993) Channel One in the public schools (Oakland, CA, Unplug).

National Audit Office (2001) Tackling obesity in England (London, The Stationery Office).

National Consumer Council (1996) Sponsorship in schools: good practice guidelines (London, National Consumer Council).

National Alliance for Public Charter Schools (2006) About us. Available online at: www.publiccharters.org/aboutus.asp (accessed 14 February 2006). 
National Union of Teachers (2006a) Academies: looking beyond the spin: the NUT's opposition to the Government's academies initiative. National Union of Teachers Briefing paper (London, NUT).

National Union of Teachers (2006b) Education not exploitation: guidance on using commercial materials in schools. National Union of Teachers Briefing paper (London, NUT).

National Union of Teachers (2006c) NUT advice on using commercial materials in schools. National Union of Teachers briefing paper (London, NUT).

Ofsted (2004) Inspection report number 258325 (London, Ofsted).

Pollitt, C. (1990) Managerialism and the public services (Oxford, Blackwell).

Rawnsley (2001) Servants of the people: the inside story of New Labour (London, Penguin).

Schor, J. B. (2004) Born to buy (New York, NY, Scribner).

Slater, J. (2003, April 4) Private sector fails to deliver, Times Educational Supplement, p. 7.

Slaughter, S. \& Rhoades, G. (2004) Academic capitalism and the new economy: markets, state and higher education (Baltimore, MD, The Johns Hopkins University Press).

Smithers, R. (2003, July 11) Fresh blow to schools privatization scheme, The Guardian, p. 10.

Smithers, R. \& Pallister, D. (2006, January 16) City academies adviser resigns after cash-forhonours accusation, The Guardian, p. 7.

Specialist Schools and Academies Trust (2005) Our supporters. Available online at: www.specialistschools.org.uk/sponsorship/corporatepartners/default.aspa (accessed 25 November 2005).

Taylor, M (2005b, October 1) Headteachers' conference sponsored by McDonald's, The Guardian, p. 4

Technology Colleges Trust (2002) Seeking sponsorship: a guide for schools (London, Reliance Press).

US Charter Schools (2006) Answers to frequently asked questions. Available online at: www.uscharterschools.org/ at (accessed 8 February 2006).

Which? (2001) School promotions: the true cost of promotion, Which?, December, pp. 8-10. 